\title{
Solar Powered Mechanical Ventilation: A case study
}

\author{
Aslı Birtürk ${ }^{l}$, Orhan Ekren ${ }^{1, *}$, Sinan Aktakka², Özdem Özel, Macit Toksoy \\ 1 Solar Energy Institute, Ege University, Izmir, Turkey \\ 2 Loadstar Izmir, Turkey
}

\begin{abstract}
In this study, a solar powered mechanical ventilation unit has investigated and tested in terms of efficiency and performance. Test unit can be divided into two parts, the first one is ventilation unit with 370 $\mathrm{m}^{3} / \mathrm{h}$ max airflow rate and max $167 \mathrm{~W}$ fan power provides fresh air for a residency and recovers heat from the climatized exhaust air. Total area is $70 \mathrm{~m}^{2}$ for the residency and total occupant is four. The second part of the test system is solar energy power system with two $325 \mathrm{~W}$ polycrystalline photovoltaic panels, an inverter and two batteries. The mechanical ventilation unit has energized by a solar photovoltaic system; if the solar energy is not available then ventilation unit has connected to the national electricity grid. This is an alternative option to consumers to use electricity by the grid in case the PV system does not produce enough energy because of the usage or the technical problems or the weather conditions based on the seasons. On the other hand, in some cities, number of photovoltaic panels rolled up upper number according to solar energy potential and therefore resulted excess electricity has assumed to sell to the national grid. According to the results, the test system is able to operate at maximum ventilation necessity and power consumption without grid connection in Izmir. Furthermore, we have compared Izmir and Romania in accordance with feasibility for the same mechanical ventilation system at max flow rate and required ventilation rate is determined depends on daily usage scenario of the room.
\end{abstract}

\section{Introduction}

People mostly spend their time in indoor environment such as school, office, home, etc. Researches revealed that indoor air is more polluted than outdoor air about 25 times. As we know that indoor air quality has direct effect on our health. For example, the World Health Organization (WHO) categorizes polluted ait in the same category with cigarette because of cancer risk. There are two main pollution sources in buildings;

i) Materials, equipments, (such as computer, electronic devices, oven, paint, coating, furniture etc.)

ii) People in the building

Thus, proper mechanical ventilation is mandatory for all type buildings for the health and higher indoor air quality. In a mechanical ventilation system, sufficient fresh air is sent into the indoor environment and polluted indoor air is exhausted to outside. During the ventilation, energy also removed with climatized (heated, cooled, humidified, dehumidified) indoor air. Since lower energy consumption is another restriction for buildings, recovery of wasted energy from exhausted air by using heat recovery unit is necessary for energy efficiently ventilation of buildings. Because building ventilation systems use conventional energy to power up their fans and it is a big portion in building energy consumption (about \%30). In principle, there are two basic methods to lower energy demand for ventilation [1]:
- Reduce the ventilation flow rate

- Energy recovery from the ventilation.

For instance, according to a scenario made in Germany for residential ventilation: if the 10,20 or $30 \%$ of the building stock uses heat recovery ventilation up to 2020, the potential of energy savings is given in Figure 1[1].

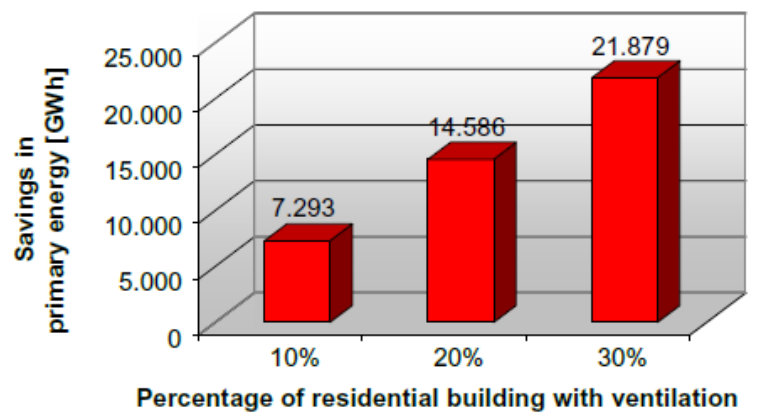
devices featuring heat recovery capability

Fig. 1. Primary energy savings potential by using ventilation systems with heat recovery in residential buildings [1].

Furthermore, using ventilation systems with heat recovery in residential buildings (as given in Figure 1) results in a $\mathrm{CO}_{2}$-savings potential of about 6 Million to/year [1]. Sustainable and low-carbon energy technologies will play an important role to overcome global energy-related $\mathrm{CO}_{2}$ target in the near future and global temperature rise problems [2].

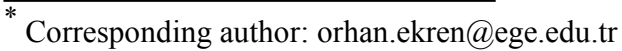


Recently, due to limited fossil fuel resources and their hazardous environmental impact reduction of energy usage in ventilation units has been pulling more attention by R\&D division of manufacturers and researchers. Furthermore, green energy technologies become one of the most important applications for HVAC systems for reduction of conventional energy usage in ventilation units.

In European commission, healthy and highly energy efficient buildings have been discussion in order to define requirement of indoor environment to ensure that energy efficient buildings according to the energy performance building directive (EPBD) [3, 4].

In the Europe and the USA, there are standards such as EN 15251, ASHRAE 62.1, ASHRAE 2.2 for ventilation rate calculation either material, equipment or people in residential buildings. For instance, EN15251 includes indoor environmental input parameters for design and assessment of energy performance of buildings such as indoor air quality, thermal environment, lighting and acoustics. In addition, the standard specifies parameters to be used for monitoring and displaying of the indoor environment as recommended in the EPBD [5].

Energy consumption of buildings depends significantly on the criteria used for the indoor environment (temperature, ventilation and lighting) and building (including systems) design and operation. Ventilation rate is one of the most important factors affecting indoor air quality and energy consumption of buildings [6, 7].

In this study, solar powered mechanical ventilation unit (with heat recovery) investigated in addition a residential ventilation system is mounted and tested in terms of efficiency and performance as a case study in İzmir, Turkey. Fan of the mechanical ventilation unit has energized by a solar PV system. According to the experimental study, ventilation unit at max flow rate $\left(370 \mathrm{~m}^{3} / \mathrm{h}\right.$ and $\left.167 \mathrm{~W}\right)$ power consumption is able to operate almost eight hours without grid connection in Izmir.

\section{Mechanical Ventilation}

Mechanical ventilation system provides sufficient amount of fresh air to the indoor environment. It has mentioned that there are standards for ventilation rate calculation. In a ventilation unit, there are supply and exhaust air fans, supply and exhaust air filters, control system, and heat recovery exchanger. The primary function is to supply fresh air to maintain indoor air quality and exhaust indoor air. Furthermore, energy recovery with ventilation is crucial in the point of view energy efficiency rules in building. Recently smart featured ventilation systems have been using to improve user comfort and energy efficiency of ventilation.

\subsection{Flow rate definition}

Indoor fresh air requirement can be defined based on standards (EN15251, ASHRAE 62.1, and ASHRAE 2.2) and $1000 \mathrm{ppm} \mathrm{CO}_{2}$ concentration level. While calculation of flow rate via standards minimum airflow rate in the rooms is determined. The first step is selecting category shown in Table 1 . The second step is to calculate minimum flow rate for the selected category in Table 2.

Table 1. Suggested applicability of the categories [8]

\begin{tabular}{|c|l|}
\hline Category & Explanation \\
\hline I & $\begin{array}{l}\text { High level of expectation only used for spaces } \\
\text { occupied by very sensitive and fragile persons }\end{array}$ \\
\hline II & $\begin{array}{l}\text { Normal expectation for new buildings and } \\
\text { renovations }\end{array}$ \\
\hline III & $\begin{array}{l}\text { A moderate expectation (used for existing } \\
\text { buildings) }\end{array}$ \\
\hline IV & $\begin{array}{l}\text { Values outside the criteria for the above } \\
\text { categories (only acceptable for a limited } \\
\text { periods) }\end{array}$ \\
\hline
\end{tabular}

Another method for indoor fresh air is minimum flow rate calculation per person at maximum 1000 ppm $\mathrm{CO}_{2}$ concentration in the room. For the flow-rate calculation, different scenarios have used such as weekday and weekend program or excess load period, daytime period, evening period, sleeping period etc. In addition, variable number of occupants also is another method while using

\begin{tabular}{|c|c|c|c|c|c|c|c|}
\hline \multirow[t]{2}{*}{ 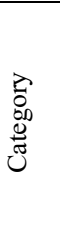 } & \multicolumn{2}{|c|}{$\begin{array}{c}\text { Airflow } \\
\text { Rate }\end{array}$} & \multicolumn{2}{|c|}{$\begin{array}{l}\text { Living room } \\
\text { and } \\
\text { Bathroom, } \\
\text { outdoor air } \\
\text { flow }\end{array}$} & \multicolumn{3}{|c|}{ Exhaust flow rate, $1 / \mathrm{s}$} \\
\hline & $\begin{array}{l}1 / \mathrm{s} \\
\mathrm{m}^{2}\end{array}$ & ach & $\begin{array}{l}\text { 1/s, } \\
\text { pers. }\end{array}$ & $\begin{array}{l}1 / \mathrm{s} / \\
\mathrm{m}^{2}\end{array}$ & Kitch. & Bath & $\mathrm{WC}$ \\
\hline I & 0.49 & 0.7 & 10 & 1.4 & 28 & 20 & 14 \\
\hline II & 0.42 & 0.6 & 7 & 1.0 & 20 & 15 & 10 \\
\hline III & 0.35 & 0.5 & 4 & 0.6 & 14 & 10 & 7 \\
\hline
\end{tabular}

scenarios.

Table 2. Ventilation rates for the residences [8]

In the current study, required maximum flow rate of the $70 \mathrm{~m}^{2}(2+1$ rooms) residence was used for the selected ventilation unit power demand calculation.

\section{Experimental Ventilation System}

In this study, ventilation of a residence with the total area $70 \mathrm{~m}^{2}$ and 4 occupants has realized with a mechanical ventilation system. In Figure 2, basic explanation of the experimental system is given. 


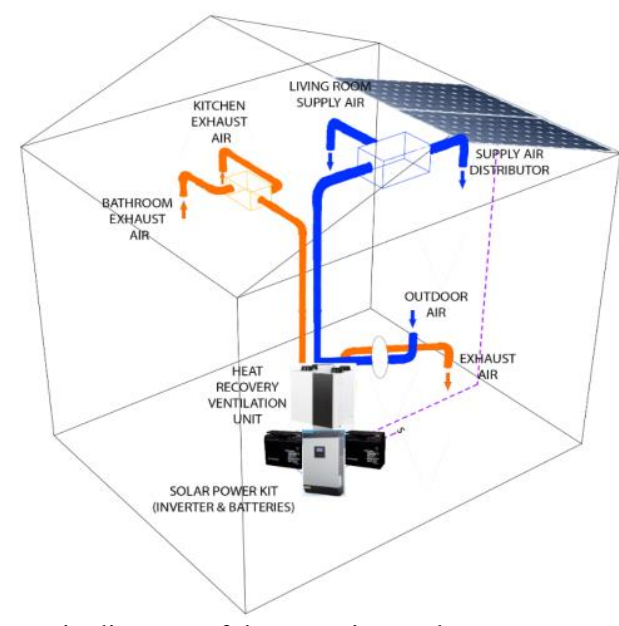

Fig. 2. Basic diagram of the experimental system

The experimental system has three components:

i) Heat recovery ventilation unit

ii) Solar energy system

iii) Control system

The heat recovery mechanical ventilation (HRV) unit powered via solar energy. Technical details of the HRV given Table 3.

Table 3. Technical specification of the HRV unit

\begin{tabular}{|l|c|c|}
\hline \multicolumn{1}{|c|}{ Specification } & Unit & Value \\
\hline Thermal efficiency & $\%$ & 90.5 \\
\hline $\begin{array}{l}\text { Maximum flow rate } \\
\text { at100 Pa }\end{array}$ & $\mathrm{m}^{3} / \mathrm{h}$ & 370 \\
\hline $\begin{array}{l}\text { Electrical power input } \\
\text { at maximum flow }\end{array}$ & $\mathrm{W}$ & 167 \\
\hline $\begin{array}{l}\text { Sound power level } \\
\text { at reference flow rate }\end{array}$ & $\mathrm{Lwa}$ & 57.3 \\
\hline Reference flow rate & $\mathrm{m}^{3} / \mathrm{s}$ & 0.072 \\
\hline $\begin{array}{l}\text { Reference pressure } \\
\text { difference }\end{array}$ & $\mathrm{Pa}$ & 50 \\
\hline \multirow{3}{*}{$\begin{array}{l}\text { Annual electricity } \\
\text { consumption (AEC) }\end{array}$} & \multicolumn{2}{|c|}{$\mathrm{kWh} /$ annual electric } \\
\cline { 2 - 3 } & $\mathrm{Warm}$ & 3.7 \\
\cline { 2 - 3 } & Average & 3.2 \\
\cline { 2 - 3 } & $\mathrm{Cold}$ & 9.1 \\
\hline \multirow{3}{*}{$\begin{array}{l}\text { Annual heating saved } \\
\text { (AHS) }\end{array}$} & $\mathrm{kWh}$ fuel gross calorific values \\
\cline { 2 - 3 } & Warm & 46 \\
\cline { 2 - 3 } & Average & 20.8 \\
\cline { 2 - 3 } & Cold & 89.9 \\
\hline
\end{tabular}

[*] COMMISSION DELEGATED REGULATION (EU) No 1254/2014 of 11 July 2014 supplementing Directive 2010/30/EU of the European Parliament and of the Council with regard to energy labelling of residential ventilation units.

Utilization of solar powered mechanical ventilation unit could decrease fossil fuel based energy utilization and increase energy performance of the building. The main components of solar energy system are PV panel, inverter, and batteries. There are two mono crystal photovoltaic panels with $325 \mathrm{~W}$ power and $19.7 \%$ module efficiency (standard test conditions: air mass 1.5; irradiance: $1000 \mathrm{~W} / \mathrm{m}^{2}$; cell temperature: $25^{\circ} \mathrm{C}$ ) used in the system. PV panels convert sunlight directly into electrical energy and produce direct current (DC) voltage.

Table 4. PV panel specifications

\begin{tabular}{|c|c|}
\hline Specification Unit & Value \\
\hline Max. Power (Pmax) [W] & 325 \\
\hline Max. Power Voltage (Vmp) [V] & 57.6 \\
\hline Max. Power Current (Imp) [A] & 5.65 \\
\hline Open Circuit Voltage (Voc) [V] & 69.6 \\
\hline Short Circuit Current (Isc) [A] & 6.03 \\
\hline Max. Over Current Rating [A] & 15 \\
\hline Power Tolerance $[\%]$ & $+10 /-0$ \\
\hline $\begin{array}{l}\text { Max. system voltage at standard } \\
\text { test conditions [V] }\end{array}$ & $1000^{* *}$ \\
\hline Solar Panel Efficiency [\%] & 19.5 \\
\hline
\end{tabular}

The schematic of the solar energy system equipment given in Figure 3.

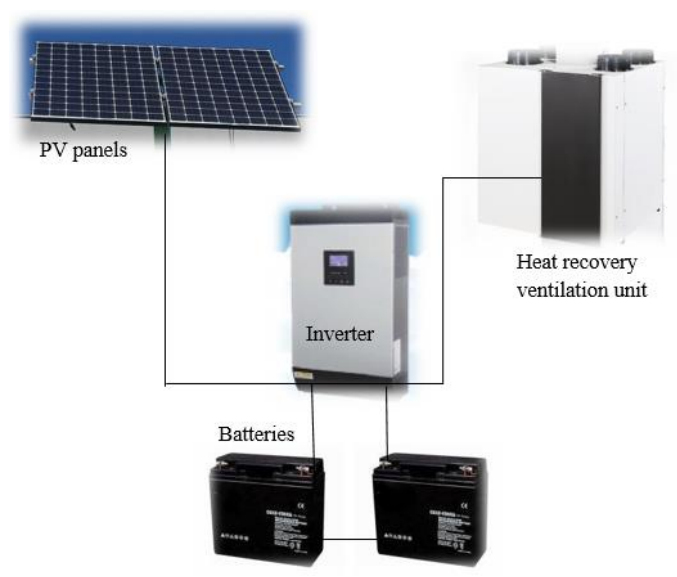

Fig. 3. Schematic diagram of the solar energy system

In order to use DC electricity in the ventilation system, which has alternative current (AC) fans, DC electricity need to be converted to AC electricity. Therefore, in the system, an inverter used with $1 \mathrm{kVA}$ capacity and $93 \%$ conversion efficiency. Furthermore, two $100 \mathrm{Ah} 12 \mathrm{~V}$ gel batteries used to operate ventilation unit for no-sun period or cloudy days also system can be used electricity from the national electricity grid in case the PV system doesn't produce enough energy by reason of the usage or the technical problems. Thus, required electricity does not have to be provided by the grid unless there is no unexpected situation.

For the case study, the photovoltaic panels are located at $38.483^{\circ} \mathrm{N}$ and $27.038^{\circ} \mathrm{E}$ in Izmir, Turkey. Solar irradiation and ambient weather data measured every 1 min period and taken from European Commission, Photovoltaic Geographical Information System (PVGIS) for unmeasured period because of failure [9]. There are some uncertain parameters while designing a solar energy system, such as global horizontal irradiance, direct normal irradiance, ambient and module temperature etc. One of the most critical 
parameter is the identification of a shadow-free location to ensure the maximum energy production [10]. Control unit is responsible from operation of ventilation unit via solar energy system or grid and management of solar energy storage task.

\subsection{Performance Evaluation}

It is obvious that solar energy systems produce higher amount of electricity at increased solar irradiation. Amount of solar irradiation on a surface changes with respect to geographical position. Europe solar irradiation map given in Figure 4 below.

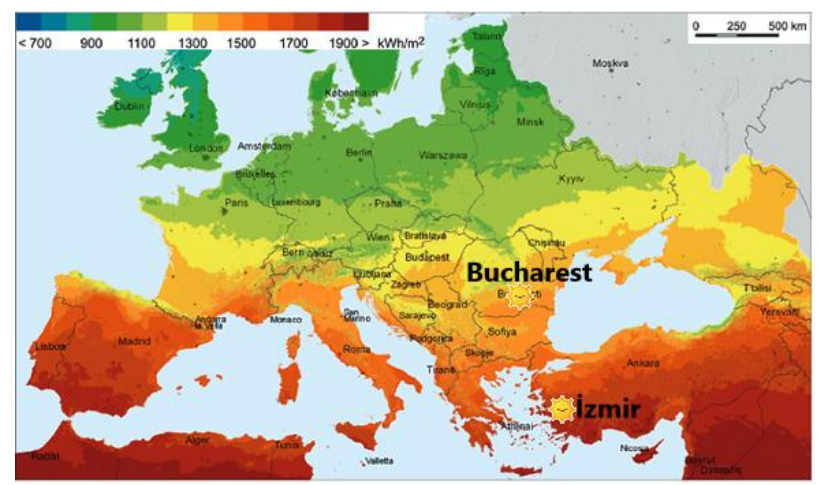

Fig. 4. Solar energy potential in Europe

In Figure 5, yearly average daily total solar irradiation given for different city in Europe and Turkey.

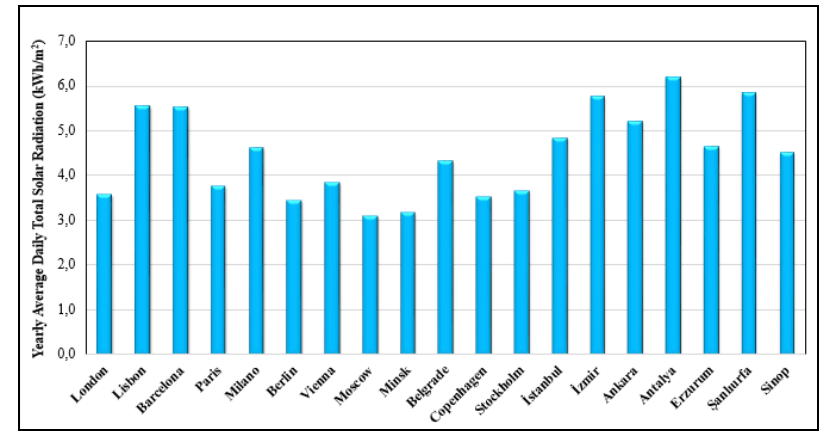

Fig. 5. Yearly average solar energy potential in some cities

For the sizing, it has considered that ventilation unit powered only solar energy during 24 hours period by using average daily total solar irradiation of the worst month. The sizing results have given for different cities in Figure 6. For the resulted power, number of photovoltaic panels are calculated for maximum ventilation necessity of a $70 \mathrm{~m}^{2}(2+1)$ residency. Figure 7 shows number of photovoltaic panels for maximum ventilation rate of residency.

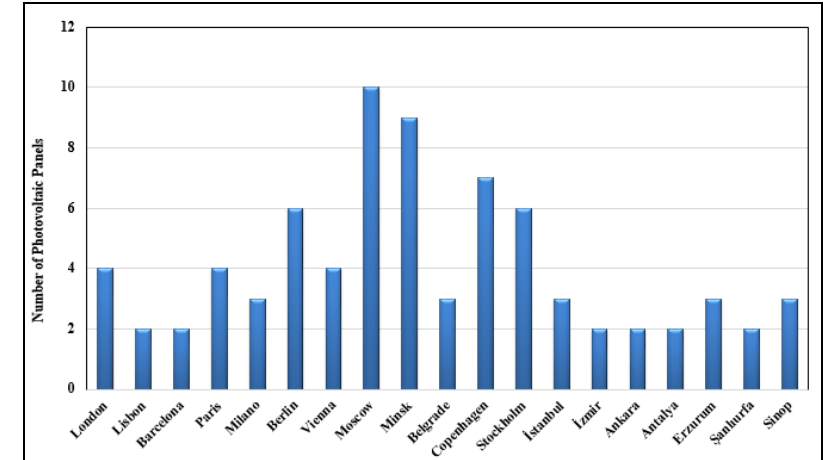

Fig. 6. Number of photovoltaic panels in some cities

In some cities, number of photovoltaic panels rolled up upper number according to solar energy potential and therefore resulted excess electricity has assumed to sell to the national grid. The yearly produced, consumed and possible sold electricity shown in Figure 7 for Turkey and Europe.

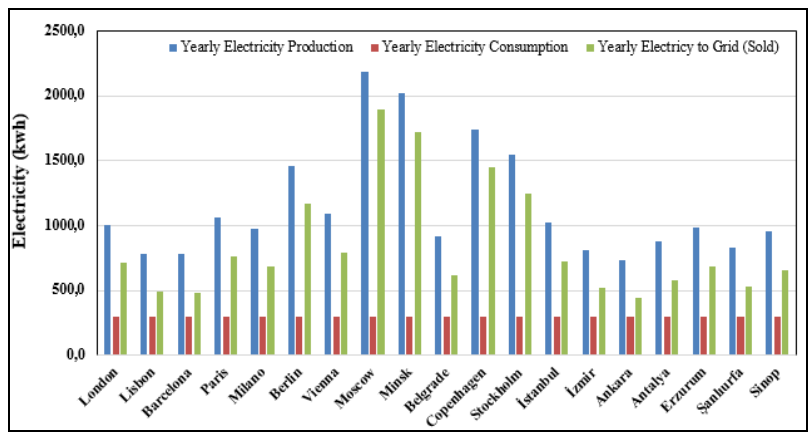

Fig. 7. Electricity from solar energy in some cities

\section{Feasibility Study of Solar Powered HRVU}

After detailed engineering analysis, a feasibility study determines whether the project is practical. Therefore, in this part of the paper economical details of the solar powered heat recovery ventilation unit has presented. In detail, profit and loss rates have examined depending on the specifications of the solar energy system components and other parameters such as geographical location where the components have supplied.

\section{i-) Izmir-Turkey Case}

The prices of the solar powered HRVU mounted in Izmir-Turkey has given in Table 5. The price for the HRVU has excluded since it has assumed that HRVU has already used in the building. Therefore, the total initial investment cost of the solar energy is 1851 Euro for İzmir. 
Table 5. System components and investment cost for Izmir

\begin{tabular}{|l|c|}
\hline Components & Cost (Euro) \\
\hline Solar Panel & 600 \\
\hline Battery & 426 \\
\hline Inverter & 425 \\
\hline Cabling & 100 \\
\hline Mounting & 300 \\
\hline Total cost & 1851 \\
\hline
\end{tabular}

To evaluate cost of produced electricity amount, yearly $1 \%$ degradation in performance of the photovoltaic panels has assumed and the photovoltaic panels have a 25-year performance guarantee based on the manufacturer data. In accordance with possible degradation, yearly produced electricity; yearlyconsumed electricity and yearly electricity to grid (assumed sold) are calculated for 25 years and given in Figure 8.

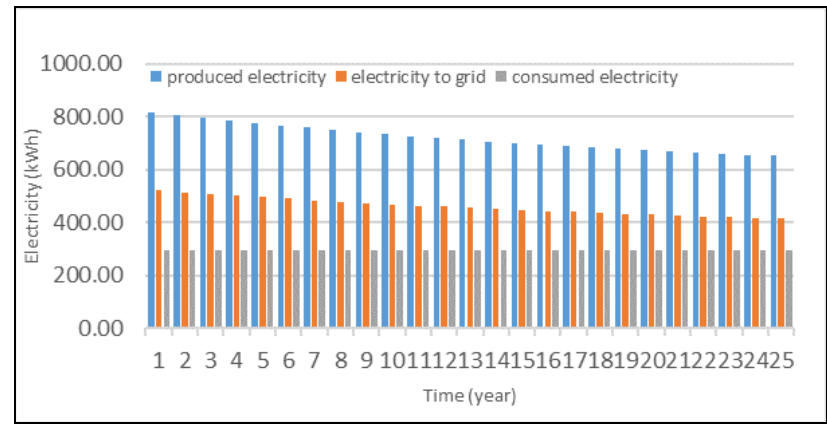

Fig. 8. Life cycle assessment of photovoltaic electricity for Izmir

Feasibility study provides produced yield, maintenance cost and investment cost of the solar powered mechanical ventilation system. For the case study location, Izmir, Turkey feed-in tariff (FIT) for solar electricity is Euro cent $11.7 / \mathrm{kWh}$. According to the results, the economic payback period is much longer than the life cycle of the system for this case study. As we know, solar FIT, electricity purchase price and investment cost vary from a country to another. Thus, it is not feasible for Turkey because of the equipment prices but might be feasible under different conditions. The results of the cost analysis of the system of Izmir given in Fig 9.

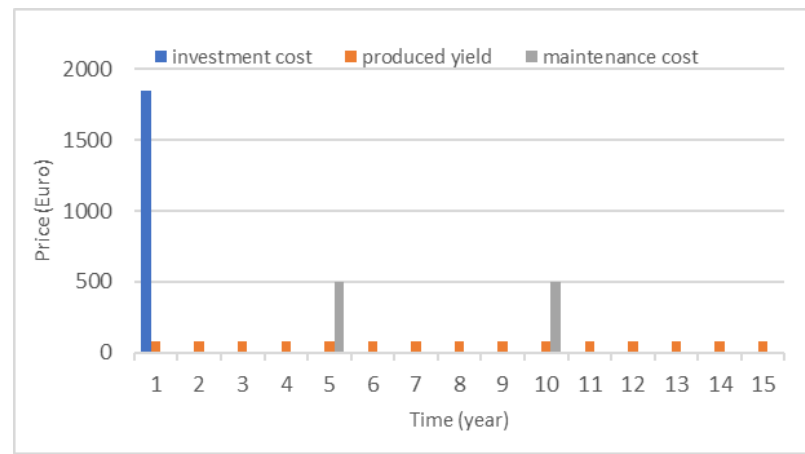

Fig. 9. Cost analysis of the system for Izmir

\section{ii-) Bucharest-Romania Case}

It is assumed that the same mechanical ventilation system at max flow rate $\left(370 \mathrm{~m}^{3} / \mathrm{h}\right.$ and $\left.167 \mathrm{~W}\right)$ is used in Bucharest. Since lower solar energy potential in Bucharest when compared to Izmir, there are three solar panels and three batteries have needed for the same mechanical ventilation unit. Thus, the feasibility study is examined for three $325 \mathrm{~W}$ solar panel, three $100 \mathrm{Ah} 12$ $\mathrm{V}$ gel batteries and a $1 \mathrm{kVA}$ inverter in Bucharest.

Considering the solar market in Romania, the cost of solar energy components has recalculated and given in Table 6. As given in the table, the initial investment cost of the solar energy system is 1216 Euro. In this study, the cost of solar energy components is one of the most important input whether the system feasible or not.

Table 6.System components and investment cost for Bucharest

\begin{tabular}{|l|c|}
\hline Components & Cost (Euro) \\
\hline Solar Panel & 342 \\
\hline Battery & 347 \\
\hline Inverter & 127 \\
\hline Cabling & 100 \\
\hline Mounting & 300 \\
\hline Total cost & 1216 \\
\hline
\end{tabular}

For the first year, produced electricity and sold (possible) electricity are calculated $9583.4 \mathrm{kWh}$ and $663.7 \mathrm{kWh}$, respectively. In accordance with possible degradation, yearly produced electricity; yearlyconsumed electricity and yearly electricity to grid (assumed sold) are calculated for 25 years and given in Figure 10.

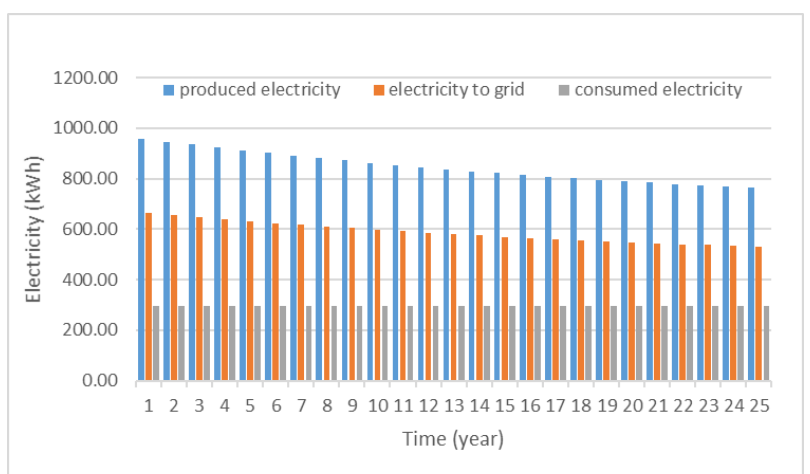

Fig. 10. Life cycle assessment of photovoltaic electricity for Bucharest

According to the Renewable, energy policy Romania recognizes the mandatory "quota" of renewable energy sources instead of the solar "feed-in tariff". In addition to the quota system, power suppliers need to obtain a green certificate (GC). The GC is an electronic document with an unique numeric code, containing information regarding the RES energy producer (the type of RES and the issuance date). For per MWh produced energy from RES a particular number of GC is issued. The number of GC issued depends on the technology used [11]. 
For the solar energy installations accredited after 01 January 2014, three GCs are required per MWh of electricity generated. Furthermore, for the solar energy installations, the issuance of two GCs per MWh further suspend from 1 April 2017 until 21 December 2020. According to the law, instead of fixed price for the GC there is a range during the period 31 March 2017 - 31 March 2032; the transaction value of one GC is at least $€$ 29.4 and at maximum $€ 35[11]$.

In our study, we calculated Euro cent 14.7 per $\mathrm{kWh}$ for solar electricity by using minimum price $€ 29.4$ per green certificate. This price has also used for the life-cycle cost analysis of the solar powered mechanical ventilation system.

The results of the cost analysis for Bucharest shown in Fig11.

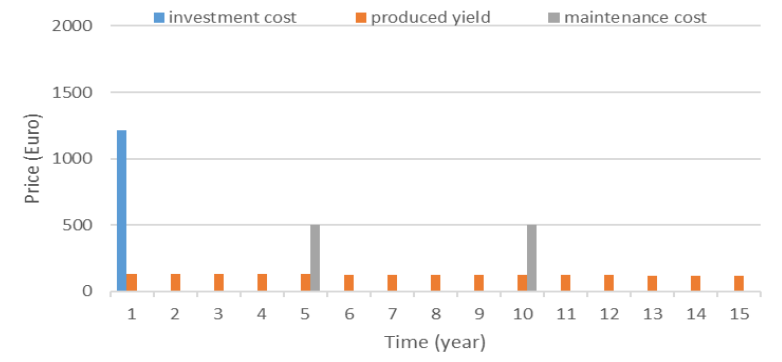

Fig. 11. Cost analysis of the system for Bucharest

To sum up, the system in Bucharest has amortized within 10 years and this result confirms that feasibility results vary from a country to another as seen for Romania and Turkey.

\section{Conclusion}

In this paper, a technical definition for solar powered mechanical ventilation system is proposed. For the maximum ventilation rate of a $70 \mathrm{~m}^{2}$ residency calculated according to a daily usage scenario and EN 15251. According to the resulted ventilation rate and power requirement of mechanical ventilation unit, a solar energy system sized for different cities of Turkey and Europe. Furthermore, we have compared Izmir and Romania in accordance with feasibility for the same mechanical ventilation system at max flow rate (370 $\mathrm{m}^{3} / \mathrm{h}$ and $\left.167 \mathrm{~W}\right)$.

Furthermore, the mechanical ventilation unit has energized by a solar photovoltaic system; if the solar energy is not available then ventilation unit has connected to the national electricity grid. This is an alternative option to consumers to use electricity by the grid in case the PV system does not produce enough energy because of the usage or the technical problems or the weather conditions based on the seasons. On the other hand, in some cities, number of photovoltaic panels rolled up upper number according to solar energy potential and therefore resulted excess electricity has assumed to sell to the national grid.
In this sense, for the case system in Izmir, a solar energy system with two $325 \mathrm{~W}$ polycrystalline photovoltaic panels, an inverter and two batteries are used. The results showed that, the mechanical ventilation system can be operated via solar power without grid connection in Izmir. On the other hand, according to the feasibility results, the economic payback period is much longer than the life-cycle of the system for Izmir. Yearly produced, consumed and sold (possible) electricity are 815.6 kWh, 294.7 kWh and $520.85 \mathrm{kWh}$, respectively.

For the same mechanical ventilation system, three 325 $\mathrm{W}$ polycrystalline photovoltaic panels, an inverter and three batteries are required since lower solar energy potential in Bucharest when compared to Izmir. The system in Bucharest has amortized within 10 years because of the lower initial investment cost and higher electricity-selling price (14.7 Euro cent $/ \mathrm{kWh}$ ) than Izmir. For the first year, the possible produced and sold electricity are calculated $958.4 \mathrm{kWh}$ and $663.7 \mathrm{kWh}$, respectively, in Bucharest.

As a result, utilization solar powered mechanical ventilation unit with heat recovery is not economically feasible for the case city Izmir with the current prices but it will help to improve renewable energy utilization and increase air quality around worldwide.

\section{Acknowledgments}

The ENEKO Company in Izmir, Turkey supported this work; therefore, the authors would like to thank the company for the financial support given to the project.

\section{References}

1. C.Händel Ventilation with heat recovery is a necessity in "nearly zero" energy buildings, REHVA Journal - May 2011

2. C. Lupangu, R.C. Bansal. A review of technical issues on the development of solar photovoltaic systems. Department of Electrical, Electronic and Computer Engineering, University of Pretoria, Pretoria, South Africa.

3. J. Kurnitski, Appropriate design of mechanical heat recovery ventilation systems for residential buildings ISH 2017 - REHVA Seminar,16 March 2017

4. S. Kephalopoulos, O. Geiss, J. Barrero-Moreno, Delia D'Agostino, D. Paci, Promoting healthy and energy efficient buildings in the European Union Joint Research Centre Report, 2016.

5. B.W. Olesen. Revision of EN15251: Indoor Environmental Criteria. International Centre for Indoor Environment and Energy, Department of Civil Engineering, Technical University of Denmark. 
6. F.Nicol, M.Wilson, An overview of the European Standard EN15251, London Metropolitan University, UK. Proceedings of Conference: Adapting to Change: New Thinking on Comfort Cumberland Lodge, Windsor, UK, 9-11 April 2010.

7. N.Brelih, O.Seppänen, Ventilation rates and IAQ in European standards and national regulations REHVA-Federation of European heating, ventilation and air conditioning associations, Rue Washington 40, B-1050 Brussels, Belgium.

8. EN15251:2007 Indoor environmental input parameters for design and assessment of energy performance of buildings- addressing indoor air quality, thermal environment, lighting and acoustics.

9. European Commission, Photovoltaic Geographical Information System Geographical Assessment of Solar Resource and Performance of Photovoltaic Technology.

10. Parimita Mohanty, Tariq Muneer, Mohan Kolhe Editors. Solar Photovoltaic System Applications, A Guidebook for off-Grid Electrification

11. Renewable energy policy database and support, Legal sources on renewable energy: Compare support schemes,1 March 2019, http://www.reslegal.eu/compare-support-schemes/ 